\title{
KESEHATAN TELINGA SISWA SMK NEGERI 2 MANADO DAN SMK NEGERI 1 TUMPAAN
}

\author{
${ }^{1}$ Sharon Tumundo \\ ${ }^{2}$ Julied Dehoop \\ ${ }^{2}$ Steward Mengko
}

\author{
${ }^{1}$ Kandidat Skripsi Fakultas Kedokteran Universitas Sam Ratulangi Manado \\ ${ }^{2}$ Bagian Telinga Hidung Tenggorok-Bedah Kepala Leher Fakultas Kedokteran \\ Universitas Sam Ratulangi Manado \\ Email: ivanova201@gmail.com
}

\begin{abstract}
In Indonesia, ear disorders and hearing loss is still a problem that society is facing. The purpose of this study is to describe the health status of the ear on vocational senior secondary school students in Manado and Tumpaan. This research used descriptive observational with cross-sectional study. The subjects are 12th grader students of Stone Concrete's majors in SMK Negeri 2 Manado and Lightweight Automotive's majors in SMK Negeri 1 Tumpaan. Based on the results of ear physical examination on SMK Negeri 2 Manado's students there are 3 people with bilateral ear wax, 2 people with unilateral ear secretions, 2 people with bilateral ear secretions and 1 person with bilateral hyperemia of the outer ear canal. While in SMK Negeri 1 Tumpaan, we found 1 person with unilateral ear wax, 7 people with bilateral ear wax and 1 person with bilateral ear edema. From the results of hearing screening at SMK Negeri 2 Manado all students are normal, while at SMK Negeri 1 Tumpaanthere is 1 person who has an unilateral ear hearing loss.The health status of the ear in SMK Negeri 1 Tumpaan and SMK Negeri 2 Manado is almost the same. This comparison shows that the health status of the ear in urban and rural areas had not much different.
\end{abstract}

Keywords: ear health, hearing screening.

Abstrak: Di Indonesia, gangguan telinga dan ketulian masih merupakan satu masalah yang dihadapi masyarakat. Tujuan penelitian ini adalah untuk mengetahui status kesehatan telinga pada siswa sekolah menengah kejuruan (SMK) di Manado dan Tumpaan. Penelitian ini menggunakan metode deskriptif observasional secara studi cross-sectional. Subjek penelitian adalah siswa kelas XII jurusan Teknik Konstruksi Batu Beton SMK Negeri 2 Manado dan jurusan Otomotif Ringan SMK Negeri 1 Tumpaan. Berdasarkan hasil pemeriksaan fisik telinga, didapatkan di SMK Negeri 2 Manado ada 3 orang dengan serumen telinga bilateral, 2 orang dengan sekret telinga unilateral, 2 orang dengan sekret telinga bilateral dan 1 orang dengan hiperemis liang telinga luar lokasi bilateral, sedangkan di SMK Negeri 1 Tumpaan didapatkan 1 orang dengan serumen telinga unilateral, 7 orang dengan serumen telinga bilateral dan 1 orang dengan edema telinga bilateral. Dari hasil skrining pendengaran di SMK Negeri 2 Manado semua siswa normal sedangkan di SMK Negeri 1 Tumpaan ada 1 orang yang mengalami gangguan pendengaran telinga unilateral.Status kesehatan telinga di SMK 1 Tumpaan dan SMK 2 Manado hampir sama. Hal ini dapat menunjukkan bahwa perbandingan status kesehatan telinga di daerah perkotaan dan pedesaan sudah tidak jauh berbeda.

Kata kunci: kesehatan telinga, skrining pendengaran. 
Telinga adalah organ tubuh yang berperan penting pada proses pendengaran dan keseimbangan, karena alat pendengaran dan alat keseimbangan ada di dalam telinga. Telinga sendiri dibagi atas telinga luar, telinga tengah dan telinga dalam.Gangguan pada telinga luar dan telinga tengah dapat menyebabkan tuli konduktif, sedangkan gangguan telinga dalam menyebabkan tuli sensorineural. $^{1,2}$

Menurut perkiraan World Health Organization (WHO), pada tahun 2005 terdapat 278 juta orang di dunia menderita gangguan pendengaran, 75 - 140 juta diantaranya terdapat di Asia Tenggara. ${ }^{3}$ Saat ini WHO memperkirakan ada 360 juta (5,3\%) orang di dunia mengalami gangguan pendengaran, 328 juta (91\%) diantaranya adalah orang dewasa (183 juta laki-laki, 145 juta perempuan) dan 32 juta (9\%) adalah anak-anak. Prevalensi gangguan meningkat seiring dengan pertambahan usia. Prevalensi gangguan pendengaran pada orang di atas usia 65 tahun bervariasi dari 18 sampai hampir 50\% di seluruh dunia.Di Indonesia sendiri, gangguan pendengaran dan ketulian saat ini masih merupakan satu masalah yang dihadapi masyarakat. Berdasarkan hasil Survei Nasional Kesehatan Indera Penglihatan dan Pendengaran di 7 provinsi tahun 1993-1996, prevalensi ketulian 0,4\% dan gangguan pendengaran $16,8 \%$. Penyebabnya, infeksi telinga tengah $(3,1 \%)$, presbikusis $(2,6 \%)$, tuli akibat obat ototoksik $(0,3 \%)$, tuli sejak lahir/kongenital $(0,1 \%)$ dan tuli akibat pemaparan bising. ${ }^{4}$

\section{METODE}

Jenis penelitian adalah deskriptif observasional secara cross-sectional.Subjek penelitian adalah seluruh siswa kelas XII jurusan Teknik Konstruksi Batu Beton SMK 2 Manado dan kelas XII jurusan Otomotif Ringan SMK 1 Tumpaan. Penelitian berlangsung pada tanggal 18 November 2013 di SMK Negeri 1 Tumpaan di desa Tumpaan Kabupaten Minahasa Selatan dan 20 November 2013 di SMK Negeri 2 Manado di Pumorow Kecamatan Tikala. Variabel penelitian adalah jenis kelamin dan hasil pemeriksaan status kesehatan telinga.

\section{HASIL}

Berdasarkan karakteristik jenis kelamin di SMK Negeri 1 Tumpaan kelas XII jurusan Otomotif Ringan persentasi terbanyak yaitu siswa laki-laki dengan jumlah 20 orang (100\%), sedangkan di di SMK 2 Manado kelas XII jurusan Teknik Konstruksi Batu Beton persentasi terbanyak yaitu siswa laki-laki dengan jumlah 10 orang (90,9\%) dan siswa perempuan 1 orang $(9,1 \%)$.

Dari hasil keseluruhan pemeriksaan fisik telinga di SMK Negeri 2 Manado ditemukan ada 3 orang dengan serumen telinga, 4 orang dengan sekret telinga, 1 orang dengan hiperemis liang telinga luar dan 5 orang normal/tanpa gejala. Pada pemeriksaan di SMK Negeri 1 Tumpaan, ditemukan 8 orang dengan serumen telinga, 1 orang dengan edema liang telinga luar dan 11 orang normal/tanpa gejala (Tabel 1).

Hasil skrining pendengaran di SMK Negeri 2 Manado didapatkan semua siswa normal (100\%), sedangkan di SMK Negeri 1 Tumpaan ada 1 orang (5\%) dengan gangguan pendengaran telinga unilateral (Tabel 2).

Tabel 1. Distribusi berdasarkan hasil keseluruhan pemeriksaan fisik telinga di SMK Negeri 2 Manado dan SMK Negeri 1 Tumpaan.

\begin{tabular}{ccc}
\hline Hasil Pemeriksaan & SMK 2 Manado & SMK 1 Tumpaan \\
\hline Serumen & 3 & 8 \\
Sekret & 4 & 0 \\
Hiperemis liang telinga luar & 1 & 0 \\
Edema liang telinga luar & 0 & 1 \\
Kelainan lainnya & 0 & 0 \\
Normal/tanpa gejala & 5 & 11 \\
\hline
\end{tabular}


Tumundo, Dehoop, Mengko; Kesehatan Telinga Siswa SMK Negeri 2 Manado...

Tabel 2. Distribusi berdasarkan hasil skrining pendengaran.

\begin{tabular}{ccccc}
\hline \multirow{2}{*}{ Skrining Pendengaran } & \multicolumn{2}{c}{ SMK 2 Manado } & \multicolumn{2}{c}{ SMK 1 Tumpaan } \\
\cline { 2 - 5 } & $\mathbf{n}$ & $\mathbf{\%}$ & $\mathbf{n}$ & $\mathbf{\%}$ \\
\hline Gangguan pendengaran unilateral & 0 & 0 & 1 & 5 \\
Gangguan pendengaran bilateral & 0 & 0 & 0 & 0 \\
Normal & 11 & 100 & 19 & 95 \\
Total & 11 & 100 & 20 & 100 \\
\hline
\end{tabular}

\section{BAHASAN}

Berdasarkan hasil penelitian, dapat dilihat ada perbedaan dari hasil pemeriksaan fisik kesehatan telinga di SMK Negeri 1 Tumpaan dan SMK Negeri 2 Manado, misalnya insidens serumen lebih banyak ditemukan di SMK Negeri 1 Tumpaan dibandingkan dengan SMK Negeri 2 Manado. Hasil pemeriksaan sekret hanya ditemukan di SMK Negeri 2 Manado saja, begitu juga dengan hiperemis pada liang telinga luar. Sedangkan untuk edema liang telinga luar hanya ditemukan di SMK Negeri 1 Tumpaan saja. Jika dilihat berdasarkan jumlah kelainan yang ditemukan, lebih banyak variasi kelainan pada SMK Negeri 2 Manado yaitu ada 3 macam kelainan antara lain serumen, sekret dan hiperemis liang telinga luar. Sedangkan pada SMK Negeri 1 Tumpaan hanya ditemukan 2 macam kelainan yaitu serumen dan edema liang telinga luar.

Pada pemeriksaan skrining pendengaran yang dilakukan pada siswa kelas XII jurusan Teknik Konstruksi Batu Beton SMK Negeri 2 Manado dan siswa kelas XII jurusan Otomotif Ringan SMK Negeri 1 Tumpaan menunjukkan hasil yang tidak berbeda jauh, dimana hanya 1 orang saja dari SMK Negeri 1 Tumpaan dengan gangguan pendengaran telinga unilateral sedangkan di SMK Negeri 2 Manado semua normal.

Dari keseluruhan hasil penelitian ini dapat kita lihat bahwa status kesehatan telinga di SMK Negeri 1 Tumpaan dan SMK Negeri 2 Manado hampir sama. Dimana berdasarkan hasil pemeriksaan di SMK Negeri 2 Manado dan SMK Negeri 1 Tumpaan yang menunjukkan hasil serumen telinga masih cukup banyak ditemukan, sama dengan pada penelitian-penelitian mengenai kesehatan telinga yang sebelumnya sudah pernah dilakukan pada anak usia sekolah dasar, dimana insidens serumen masih tergolong tinggi. ${ }^{5,6}$

\section{SIMPULAN}

Status kesehatan telinga di SMK Negeri 1 Tumpaan dan SMK Negeri 2 Manado hampir sama, menunjukkan bahwa perbandingan status kesehatan telinga di daerah perkotaan dan pedesaan sudah tidak jauh berbeda. Hal ini bisa saja dipengaruhi oleh perkembangan teknologi informasi yang sudah semakin maju sehingga kemudahan untuk memperoleh informasi tentang kesehatan telinga baik penduduk desa maupun kota sudah sama. Begitu juga dengan adanya program pemerintah tentang pemerataan pendidikan di kota dan di desa sehingga anak-anak sekolah di kota maupun di desa sudah menerima pelajaran-pelajaran yang sama tentang kesehatan. Faktor intelektual, kebiasaan-kebiasaan anak di lingkungan rumah dan keluarga serta pengetahuan umum seseorang juga dapat berpengaruh terhadap sikap seseorang dalam memelihara kesehatan dan kebersihan telinga.

\section{UCAPAN TERIMA KASIH}

Penulis mengucapkan banyak terima kasih kepada para penguji dan semua pihak yang sudah memberi masukan dan arahan serta gagasan-gagasan dalam penulisan artikel ini.

\section{DAFTAR PUSTAKA}

1. Soepardi EA, Iskandar N, Basshirudin J, Restuti RD. Buku Ajar Ilmu Kesehatan Telinga Hidung Tenggorok Kepala \& Leher 
(Edisi ke-6). Jakarta: Badan penerbit FKUI, 2007.

2. Dhingra PL. Diseases of the Nose, Throat, Ear, Head and Neck (Fourth Edition). India: Elsevier, 2007.

3. Depkes RI. Telinga Sehat Pendengaran Baik[homepage on the internet].Nodate [cited 2014 Jan17]. Available from: http://www.depkes.go.id/index.php?vw=2\&i $\mathrm{d}=840$

4. Depkes RI. Pendengaran Sehat untuk Hidup Bahagia [homepage on the internet]. Nodate [cited 2014 Jan17]. Available from: http://www.depkes.go.id/index.php?vw=2\&i $\mathrm{d}=2245$
5. Alriyanto CY. Pengaruh Serumen Obsturan Terhadap Gangguan Pendengaran (Studi Kasus pada Siswa SD Kelas V di Kota Semarang). [skripsi]. Semarang: Universitas Diponegoro; 2010.

6. Etania C. Hubungan Penyumbatan Cerumen Dengan Kemampuan Mendengar Pada Siswa-Siswi Di Beberapa Sekolah Dasar Di Kecamatan Medan Maimun Dan Kecamatan Medan Labuhan. [skripsi]. Medan: FK Universitas Sumatera Utara; 2012. Available from: http://repository. usu.ac.id/handle/123456789/38695 di akses 24 Januari 2014. 